\title{
Strengthening Citizenship Socio-Cultural Movement in the Environmental Field through Lorong Garden Program in Makassar
}

\author{
Suriaman Suriaman, Dasim Budimansyah \\ Civic Education Department \\ Universitas Pendidikan Indonesia \\ Bandung, Indonesia \\ surya.atoz@student.upi.edu, budimansyah@upi.edu
}

\begin{abstract}
This study aims to provide an overview of the implications of approaches and strategies as an effort to strengthen the awareness and concern for the environment as a citizenship socio-cultural movement through a lorong garden program. The research was conducted in three sub-districts in Makassar City. The research method used is qualitative approach with case study method. Data was collected through observation, interviews and document analysis. Data were analyzed using Miles and Huberman model which consists of the activities data reduction, data presentation, and data verification. Data validity using data triangulation technique. The results showed that the lorong garden program provide a significant impact on environmental sustainability in urban areas through urban farming with infill urban agriculture concept with a topdown implementation system. This study aims to present research results that strengthen awareness and concern for environmental through citizenship socio-cultural movement with a cultural approach.
\end{abstract}

Keywords-socio-cultural movement; citizenship; environmental; lorong garden program

\section{INTRODUCTION}

Uncontrolled urban population growth led to the emergence of land clearing activities for the settlements. Increasing the needs of residents to the needs of residential space resulting in narrowing of spaces in a region. As a result, there is a deterioration in environmental quality. Increased urban development activities led to a number of problems due to land conversion and changes in land use intensity. One immediate impact is the reduced green space, both in private and public proportions. Urban sprawl that leads to the suburbs has changed the function of agricultural lands into settlement land. This change affects dependence on food needs for the supply of agricultural products in urban areas in particular.

In the central city area, impacts on the high level of population density and building both in terms of natural growth and migration due to high attractiveness by residents. Narrow road access due to the shifting of open space users on private lands into massive buildings. Narrow road access is transformed into unkempt passages and tends to decrease the visual quality and green environment. In areas with high population densities, forming a residential population with slums, unkempt conditions, and an impact on the degradation of negative socio-cultural values of citizens.

Program planning is included in regional development planning documents as a description of the vision, mission and program of regional heads during the 5 (five) annual government period. While the lorong garden program is a description of the vision of the RPJMD Kota Makassar Year 2014-2019 (Medium Term Development Plan Area), the arrangement of a productive aisle is targeted in restoring the urban spatial into a comfortable city for all levels of society.

Lorong garden program is a program that utilizes the gang as an agricultural land by planting several types of plants such as vegetables, fruits, family medicinal plants, and ornamental plants. The purpose of this program is to empower communities in developing farm-based vertical garden in the alley on the city housing.

So far, environmental conservation through the lorong garden program in Makassar is considered effective with the system from the government to the community in a top-down manner because the handling and arrangement of the aisle is more evenly distributed and spread all over from the center to the edge of urban areas. The program runs optimally through the active role of the government by involving citizens in a massive and direct as a socio-cultural movement to jointly organize the narrow city corners with a number of types of plants that adorn the alley.

Some similar programs that have been applied by Surabaya government with green and clean concept. However, different from the strategies and approaches that are done. Lorong garden program is intended to set up a comfortable and productive alley, so that residents who live in the alley can feel the comfort of space in its territory through the arrangement of green open space vertical and improve welfare with agricultural programs in the city "urban farming". The concept of urban farming is also implemented by the people of Bandung Gardening as a social movement of the bottom layer of society (bottom-up). The concept is also different because it focuses on exploiting non-productive lands for reforestation in some locations [1]. However, it is considered less effective 
because it only occurs in several locations with small scale. So, it does not have a significant macro impact.

In realizing a better environment, citizens have a big role as drivers of change. Therefore, strengthening the socio-cultural movement in the field of environmental citizenship in Makassar embodied in programs such as watering of lorong garden along the aisle, regular communal work, sorting the waste, study hall, and do nursery plants without the need to be supervised, directed, and routinely monitored by the government. Strengthening awareness and concern for environmental sustainability as a manifestation of attitudes of citizens who care for each other, empathy, independence, discipline, responsible, and clean according to the sociocultural conditions they have.

\section{THEORETICAL}

The theory of green constitution as an umbrella of environmental law that places the state constitution in the protection of the environment as an important consideration [2]. The position of the green constitution in response to the country's concern over the decline of environmental function. Green constitution to constitutionalize the norm of environmental law into the constitution through raising the standard of environmental protection to the constitution level. This theory is part of the principle of sustainable development with environmental insight and protection of the environment as a strong foothold in the legislation. Green constitution emphasizes the importance of environmental sovereignty, especially in areas that use the law as the basic state in governing citizens according to their rights and obligations.

In environmental theory, as disclosed by Dobson that environmental citizenship is a citizen conscious of his rights and obligations with a high commitment regardless of punishment, loss, economic rewards, or social status to always maintain the environment to become a civilized citizen [3]. The essence of human beings not only as social beings, but also ecological beings who have responsibility in seeking environmental sustainability.

In Canada through the Canadian Ministry of the Environment used the term Citizenship in 1990 as a dominant position in the field of green politics. The Canada government realizes that the success of environmental management cannot be done by the government through the existing rules without the cooperation of the citizens. The government only encourages citizens to be good citizens for the environment and even make sacrifices for the environment. The Canadian government also promotes green citizenship with the aim of delegating responsibility to citizens through environmental policy [4].

As ecological citizenship theory put forward by Luque [4] that lifestyle changes and collective actions can be mutually reinforcing to environmental sustainability. Even the participation and motivation of the citizens is needed to protect the environment as a collective action. Governments have the authority to provide personal responsibility and act in accordance with their obligations can help raise citizens' awareness that their behavior and attitudes can make changes to the environment.
Furthermore, according to Yuniarto [5], ecological intelligence is important as an effort to strengthen the paradigm of sustainable development. According to him, three approaches needed to build citizens' awareness of environmental conservation are: a) systematic, integrated, and sustainable education approach (psych-pedagogical development); b) a socio-cultural approach through approach and development local wisdom on environmental preservation (socio-cultural development); c) the approach of government political intervention relating to the substance of law and its consistent enforcement (socio-political intervention). These three approaches as the basic capital in developing the ecological intelligence of citizens.

In Indonesia, the theory of civic education must be based on and value of Pancasila and moral, embodied in the order of citizenship in accordance with Undang-Undang Dasar Negara Republik Indonesia Tahun 1945 (Constitution of the State of the Republic of Indonesia), live intact, upright, and lasting in the Unitary State of the Republic of Indonesia (NKRI) sociocultural life live in harmony and peace according to the meaning and spirit of Bhinneka Tunggal Ika [6].

Residents of the city who became part of the community as well as the subject of research is a citizen who in fact plays an active role in contributing optimally in public engagement. Therefore, through Civic Education developed in the tradition of Citizenship Education whose purpose is in line with national objectives. The general purpose of developing Civic Education in the context of non-formal education in order to shape its citizens into good citizens, smart citizens; both intellectual, emotional, social, and spiritual intelligence and participate in the life of nation and state (to be democratic citizens).

Civic Educations a synergistic citizenship social-cultural movement is conducted in an effort to build civic virtue and civic culture through active participation intelligently, democratically and religiously in their environment [6]. The context of civic virtue becomes the peculiarity of citizens' goals in building an attitude of responsibility for the welfare of others and his satisfaction in living life based on the principle of humanity.

Citizens who have civic responsibility, namely pride and responsibility in the state and able to participate in community life. Government is expected to have a strategy in the development of socio-cultural movement as an increase of individual development, participation citizens and responsible citizenship [7].

Based on the basic theory of socio-cultural influence of citizenship is Max Weber, a German sociologist. In his theory, Weber explained that citizens play a big role in developing the environment. Because, citizens have a social value, cultural value, and an interesting institutional framework in which they live. Basically, Weber's theory explains that the sociocultural system in which citizens can influence the behavior of individuals becomes collective.

Socio-cultural approach in the success of government programs has also been applied by Iran in the field of environment. Socio-cultural approach is considered a strategy that must be done by involving citizens in composing, 
implementing and evaluating the program in accordance with the values existing culture [8].

The socio-cultural environment comprises all elements, including beliefs, values, attitudes, habits, behavioral forms and community-style life developed from cultural, religious, educational and social conditions. These elements are learned and shared by the community and transmitted from generation to generation within the community [9].

Strengthening Civic Education as a citizenship sociocultural movement becomes one of the alternative endeavors in reducing environmental damage that is increasingly worrisome. Without any awareness and caring together, nature and all the ecosystems in it will experience severe degradation.

To strengthen Civic Education as a citizenship sociocultural movement special for citizens, the government makes a kind of policy simulation in the field of environment in order to reinforce the attitude of togetherness in the community. Awareness to each other to preserve the environment is categorized into public character, because as a form of citizens' concern towards other citizens [10]. Civic Education as a citizenship socio-cultural movement that acts as a vehicle for self-actualization of individual citizens as well as groups in accordance with their rights, obligations and cultural social context, through intelligently and responsibly active participation.

Civic Education as a citizenship socio-cultural program that is academically known as community civic education [6] in the context of social community in society is manifested in the form of social activities of good citizens formed by the community citizens as well as government programs related to deep-rooted social activities and to strengthen the nation's culture.

It can be said that community civic education is a good place for socio-cultural activities conducted by the academic community, practitioners, officials, businessmen, and communities within the scope of schools and communities in the community. The extent of Civic Education is not only within but outside the classroom and by correlating with community communities [11].

Methodologically, Civic Education as a scientific field of social studies one of which has a systemic paradigm in the social cultural domain as the concept and praxis Civic Education in the community [6]. In this paper, the study of Civic Education as a citizenship socio-cultural movement focused on the activities undertaken by citizens in the field of environment as a form of implementation of the lorong garden program conducted by the government of Makassar.

The aspect that is built in the socio-cultural movement of citizenship is a social institution with a system of values and norms, therefore the community and community in this case need to provide public space for citizens to cultivate citizenship [10].

According to Dagger [12], the active participation of citizens in government efforts to instill virtue in the form of motivation to citizens through effective and responsible assistance. An effective environmental issue is addressed with the participation of all citizens concerned. The moral community is not only limited to the social community, but includes the entire ecological community. Awareness both individually and in groups is a change of attitude shown as a decision based on ethical attitudes voluntarily [13].

According to Burke, citizen participation is not a value, but rather as a strategy, and the terms of the organization. Furthermore, Burke identified [14] that there are five strategies in citizen participation: education therapy, behavioral change, supplement staff, cooptation, and community power.

Departing from previous theories, the researcher informs that in this article describes citizen participation as part of the socio-cultural movement in the field of environment in urban agriculture activities as a manifestation of awareness and concern as citizenship environmental. Behavior which is shown as a form of socio-cultural movement that promotes the common interest rather than self-interest based on the cultural values it has.

\section{METHOD}

Research method used is qualitative approach with case study research design. The research was conducted in 3 subdistricts of Mamajang sub-district, Tallo sub-district, and Biringkanaya sub-district in Makassar. The location of the study was chosen based on the background of the research point representing the city center, the middle town, and the suburbs implementing the program. The subject of research is the government of Makassar starting from the department, subdistrict, urban village, RT/RW as the implementer of the lorong garden program and the citizens as the target of the program which amounted to 28 informants.

The process of collecting research data collected through observation, interview, and analysis of research documents. Data analysis using Miles and Huberman model with data analysis technique consist of data reduction, data presentation, and data verification [15]. Data validity using triangulation techniques from data sources and data collection techniques. The issue of ethics in qualitative research reporting is to share information about research findings openly.

\section{RESULTS AND DISCUSSION}

Urban farming or urban agriculture is a key concept in creating a green city environment. Contributions from urban agriculture in this context include the potential of waste to be recycled back into organic waste, reducing energy use by fresh food providers, and improving urban ecology. Urban agriculture is one of the strong and positive activities for urban people who make efforts in controlling food security, social ills and environmental degradation within a community. Urban agriculture provides food, employment, environmental enhancement, education, beauty, inspiration and hope [16].

In Makassar, one of the cities in Indonesia, made a program with the concept of urban farming is lorong garden program. The lorong garden program developed into a productive program by inserting the concept of agriculture in city alleys. The concept of insertion of agricultural space in these urban massive areas, developed into the concept of "infill urban 
agriculture". The term is similar to vertical gardens performed in countries such as India, America, and Dubai City.

To simplify the concept in question, I attach as in the following fig. 1:

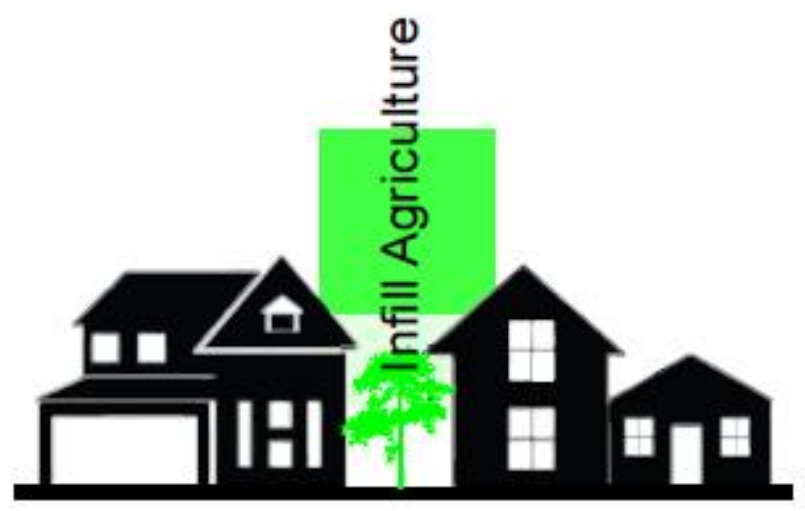

Fig. 1. Infill Urban Agriculture concept of lorong garden program.

The concept of infill urban agriculture referred to in the lorong garden program is city gangs designed with vertical gardens planted with productive crops such as vegetables, fruits, ornamental plants, and family medicinal plants. These types of plants are part of urban environmental arrangement. For types of vegetables and fruits, the plantation products can be consumed by the people and can be sold through the Badan Usaha Lorong (BULO) located in each aisle. The Badan Usaha Lorong is an institution formed by the government that aims to accommodate agricultural products of citizens with economic value.

The lorong garden program by the government of Makassar aims to change the previous alleys with dirty, arid, slum, dark, narrow conditions, endemic places of the disease, and crime centers to be clean, green, and economic drivers of citizens as a form of food security. Macro, this program can be seen as non-formal education, ecology, and microeconomics in the environmental field in urban areas. In addition, the significant impact that is gained is to change the mindset to citizens to be more aware and care about the environment.

Lorong garden is a program of Makassar government in growing awareness and concern for environment in urban area. The key to the success of the lorong garden program is community participation. In Indonesia, community participation is called "gotong royong". Communities play an important role in developing, maintaining, and caring for their respective environments. To involve the community in strengthening civilization to the environment, the government has a strategic role in the form of policy makers, policy implementers, and policy evaluations. In this article, is discussed about the lorong garden program which is basically a form of socio-cultural movement in responding to the government's challenge in innovating in the environment as a strategy to raise awareness, awareness, and strengthen the civilization of citizenship to the environment. The role of government in the field of environment in the future from conventional services to service of results [17].
Some of the findings of success in the lorong garden program are as in the following table 1:

TABLE I. FINDINGS THE SUCCESS OF LORONG GARDEN PROGRAM

\begin{tabular}{|l|l|}
\hline \multicolumn{1}{|c|}{ Indicators } & \multicolumn{1}{c|}{ Changes } \\
Gatal of Lorong & $\begin{array}{l}\text { An increase in the number of altered passages into } \\
\text { lorong garden by 65\% of the 7812 aisle from 2015- } \\
2018 .\end{array}$ \\
\hline $\begin{array}{l}\text { Knowledge } \\
\text { level }\end{array}$ & $\begin{array}{l}\text { Increased knowledge of residents who live in the hall } \\
\text { who do not know how to grow vegetables, fruits, and } \\
\text { family medicinal plants in the yard of the house to } \\
\text { know and understand, thanks to the assistance of } \\
\text { agricultural extension workers }\end{array}$ \\
\hline $\begin{array}{l}\text { Change } \\
\text { attitude }\end{array}$ & $\begin{array}{l}\text { Changes in attitudes and behaviors of people who } \\
\text { tend to apathetic and negative aisle become active and } \\
\text { positive with the relationship between neighbors more } \\
\text { closely intertwined.. }\end{array}$ \\
\hline $\begin{array}{l}\text { Changes } \\
\text { behavior }\end{array}$ & $\begin{array}{l}\text { Changes in the behavior of alley people with the habit } \\
\text { of littering to be more loving environment. waste of } \\
\text { economic value such as plastics, paper, bottles and } \\
\text { others in the container to be channeled through Bank } \\
\text { Sampah formed in every village for sale. From these } \\
\text { results, able to provide economic income for the aisle } \\
\text { citizens. }\end{array}$ \\
\hline $\begin{array}{l}\text { Increased } \\
\text { Production }\end{array}$ & $\begin{array}{l}\text { Increased production activity in the aisle, where } \\
\text { people can pick vegetables, fruits, and family } \\
\text { medicinal plants grown in home lawn and along the } \\
\text { aisle to be subsequently consumed with family and } \\
\text { other residents. }\end{array}$ \\
\hline
\end{tabular}

Source: results of the analysis of documents, interviews, observation

The success of the lorong garden program, cannot be separated from the social touch made by the government. As the data obtained, that the number of alleys in the city of Makassar as many as 7812 alleys scattered in 15 districts. With that amount, a proof of success with a span of 3 years of implementation is able to change the $65 \%$ of previously ordinary passageways into lorong gardens.

The results of the study indicate that the government has an important role and strategy in empowering urban communities in the context of institutional driven by the motivation and legitimacy of the government. The program also develops topdown controls, cooperation, and communications between structural work units through the Office of Food Security and Agriculture and Fisheries Service, sub-district government, village government, and RT/RW head in providing encouragement and assistance within fix the vertical gardenbased alley. The advantages of this vertical garden system are that they can be applied to narrow land, save land use, and are easy to implement. As Voss [18] argues that the location or land required for applying the vertical garden concept can be done either inside or outside, at the center or the suburbs, and are dynamic in nature which can be adapted to the conditions of available farmland.

In some other countries also apply vertical garden system. Among other things, Canada is using the top of the building as a gardening land. In some countries also like Singapore, South Korea, Japan, the Netherlands, Sweden, and some cities in the United States utilize land or buildings that have non-productive land to be used as agricultural land in the city [19]. This is slightly different from the concept of lorong gardens that utilize narrow alleys as agricultural land with a vertical garden 
system. This is one form of innovation in the field of urban agriculture that can be used as a model to be developed in other countries.

Vertical garden concept is also done in Dubai City by correlating the modern concept with a touch of sophisticated technology in agriculture. The application of vertical garden becomes a functional part of the urban system by occupying a special land on a sustainable basis. Design, equipment, plant types, and animals are applied in detail. This is certainly costly [20]. However, the concept of lorong garden with vertical garden systems occupies a narrow aisle utilizing waste items such as used bottles, gallons, old sacks, and other objects that can be used as a growing medium and create a kind of vertical shelf model as the place.

The benefits derived from vertical garden concepts on the environment, farming in cities conserving biodiversity, reducing waste and losses and energy cytaly used to produce and provide food for citizens. In addition, urban agriculture has the potential to replace the agricultural industry and could be a better alternative in minimizing the damage caused by conventional open field agriculture [19].

Lorong garden programs have a positive impact by raising awareness and awareness of the people in the aisle for the importance of a clean, green and well-ordered aisle environment. In addition, it also improves the relationship between families and reduce criminal acts that often occur in the alley. Urban agriculture can also have great potential to empower and educate citizens about the environment in government planning in carrying out its policies [21].

Several strategies to strengthen the socio-cultural movement is to hold an integrated work that is done once a week in 998 RW in Makassar in rotation, creating a public engagement program or touch the heart of the program addressed to the government urban village to do door to door visit 20 homes every week, doing cultural approach by using the special language area of Makassar. The use of regional languages is considered effective in disseminating to the people of Makassar, and conduct socialization through the mural culture of Makassar character in the form of pictures and writing contains an invitation to always keep the environment.

The approach strategy adopted by the municipal government in carrying out this program is to go down the aisle to participate in the work of devotion, to motivate and to give an example in environmental management. This approach is known as the heart touch program. The objectives of this program are the sub-district, village, RW/RT heads to invite the community by opening a discussion room to find the right solutions to the problems found in the implementation of this program.

In addition, the municipal government also involves several private parties as a form of acceleration of revamping the existing aisle. Some altered corridors are the result of private social responsibility [22]. One form of social movement of citizens in protecting the environment is to utilize some inorganic waste by replacing its function into a container or pot where the plant. The inorganic waste is like used buckets, large plastic bottles, sacks, and several other types.
One of Makassar government's strategy in developing the awareness and concern of the citizens to their environment is by using regional terms such as lorong, rantasa, tangkasaki, dottoro, sombere, mabelo and mural or wall message of regional nuance. Psychologically citizenship, it is able to provide understanding as a form of socialization to citizens about government programs as a form of socio-cultural touch.

Thus, socio-cultural in relation to the environment, can be defined as a movement consisting of all elements of the social and cultural system of citizens either positive or negative which may affect the emergence of citizenship, where behavior and performance, and development of citizenship in general. All elements such as the condition of values, thoughts, and actions of citizens to the environment consist of the socio-cultural movement of citizenship.

Social movements that are routinely done by the alley residents in taking care of the environment are watering the plants, sorting garbage, planting, and doing mutual cooperation. In addition, incidental movements are environmental activities at certain moments such as recitation of the aisles alternately, processing inorganic waste into handicrafts, and a touch program of heart to invite other citizens to participate in revamping the aisle around it.

The success rate of the lorong garden program is interpreted as a voluntary movement for the public interest that departs from sincerity to contribute to environmental sustainability and food security. Through this program of socio-cultural movement, is expected to strengthen the attitude of volunteerism as a form of moral effort to overcome the problems in the field of environment without accompanied by the existence of personal interests, but arise by itself. As according to Tocqueville and Constant [23], the apathy of citizens tends to lead democracy in a worse direction.

The model of socio-cultural movement in the lorong garden program is considered as an important model as part of the government's policy to answer one of the challenges and problems that are engulfing the Indonesian nation, namely the erosion of the spirit of gotong-royong as a cultural characteristic of society and the Indonesian nation by individualistic attitude especially in the field of environment.

Challenge Government policy in strengthening individual citizens into collective action is one of the keys in overcoming the environment. Governmental approaches to addressing environmental issues by introducing regulatory policies, applying regulations and offering economic incentives, mobilizing grassroots governance such as RT/ RW as an important agent of change. This confirms that citizen involvement and participation will improve and accelerate the course of a policy in the long term [3].

The form of citizen participation which is shown in the activities of participation in the form of material and nonmaterially done voluntarily. Whereas, the form of government participation in participation activities is to motivate the citizens every time they visit the community and present directly in the work activities devoted every weekend in turn.

From the educational aspect, in developed countries, the concept of urban agriculture is used as an educational facility 
by providing information on ideas and methods of production and utilization of food. As happened in Gotham City, New York, where outsiders are volunteered to visit the vertical garden site. When people visit, they will share knowledge with others and consequently knowledge will spread and generate further participation [19]. Social communication efforts among citizens to succeed the program is expected.

The case studies occurring in northern England, urban agriculture provides social impact through beneficial activities, enhancing social cohesion and engaging people together in exploiting the social communal spirit [24]. From the social aspect, the main purpose of urban agriculture is not only to improve agriculture but also to serve society by making people closer to people and closer to nature. Therefore, providing for food while educating citizens [19].

Many case studies show that urban farming can make an important contribution in helping the urban poor to meet food needs. However, a number of obstacles faced in achieving that goal is one of the limited land owned [24].

Similar cases also occur in Flint, Michigan. Where, the concept of urban agriculture has long been run by residents who reside in the area. However, the government created a legal framework to regulate with the aim that urban agriculture is better organized. In the formulation of the legal framework, the government involves the community in the formulation of policies to find appropriate solutions in implementing urban agriculture [25].

Unlike the case with the concept of urban agriculture in Dhaka City, Bangladesh. Rooftop gardening is considered to be one of the most effective methods of meeting food needs and nutritional balance for citizens [26]. While in Brazil, urban agriculture is applied to home consumption with low economic income as a form of food security, economic and production problems, and nutrition fulfillment for citizens with the concept of urban vertical gardens [27].

As Brundland reports from the survey results show that vertical garden concepts show frequency results in sustainable development puts environmental, social, and economic aspects in order of significant change [19]. Can be interpreted that, urban agriculture system with vertical garden concept not only solve environmental problems alone, but social problems such as apathy, uncaring, and individualistic attitude can be improved.

Different planting movements between developing and developed countries are a problem of food security. Because the main goal of vertical gardens is the provision of food in low-income countries and contributes to the basic needs of local food. In the city, the consumer population is very high and more poor people in this population are also limited or no access to good food [19]. On the other hand, vertical gardens in addition to food solutions, but also as a concept of urban environmental sustainability.

As disclosed in a study conducted by McKeown-Ice and Dendinger [28] that offers the concept of socio-cultural building in environmental education in the scope of knowledge as an evaluation effort in environmental education should consider the use of the list validated as a tool to prevent the social sciences systematically incorporated in environmental education materials, curricula, courses, and programs.

As the research conducted in the Netherlands by Boogaard, Oosting, and Bock [29] concludes that agricultural systems have more value than food production, but citizens also have to get closer to nature as part of a socio-cultural system. Therefore, ethical issues in sustainable urban agriculture are influenced by socio-cultural concepts within social groups, places and times of understanding the context of interdependence.

\section{CONCLUSION}

The lorong garden program with the concept of infill urban agriculture applied through the Makassar government policy on the alleys of the city can form a collective awareness and concern in a socio-cultural movement of citizenship in the field of environment. This movement was formed through strengthening the involvement of citizens as a form of moral morality of citizenship as a supporter of environmental citizenship.

The implications of the results of this research are the socio-cultural movements of citizenship as an effort to strengthen the civilization of citizenship through the active participation of intelligent, democratic and religious in the field of environment. This citizenship participation as a form of community education to provide knowledge, character and skills to citizens in improving ecological intelligence.

In this study provides recommendations to serve as role models by government to be replicated in each city in accordance with the potential and need to strengthen the sociocultural environment. Also, in the context of Civic Education can take advantage of such a program as an authentic learning resource.

\section{ACKNOWLEDGEMENTS}

Thanks to the government and citizens of Makassar who are willing to serve as subjects and informants in this research. In addition, thanks to the help and hospitality provided during the process of collecting research data is a convenience in completion of research within the specified time.

\section{REFERENCES}

[1] W. H. Prasetiyo, D. Budimansyah, and N. Roslidah, "Urban farming as a civic virtue development in the environmental field," Int. J. Environ. Sci. Educ., vol. 11, no. 9, pp. 3139-3146, 2016.

[2] J. Asshiddiqie, Green Constitution: Nuansa Hijau Undang-Undang Dasar Negara Republik Indonesia 1945. Jakarta: Rajawali Pers, 2009.

[3] A. Buko, "Environmental Citizenship for Sustainable Consumption," Universsity of Twente Enschede, 2009.

[4] C. Melo-Escrihuela, "Promoting Ecological Citizenship: Rights, Duties and Political Agency," Acme, vol. 7, no. 2, pp. 113-134, 2008.

[5] B. Yuniarto, Membangun Kesadaran Warga Negara Dalam Pelestarian Lingkungan. Yogyakarta: Deepublish, 2013. 
[6] U. S. Winataputra, Pendidikan Kewarganegaraan: Refleksi HistorisEpistemologis dan Rekonstruksi untuk Masa Depan. Tangerang Selatan: Universitas Terbuka, 2015.

[7] A. A. Wahab and Sapriya, Teori dan Landasan Pendidikan Kewarganegaraan. Bandung: Alfabeta, 2011.

[8] F. Kalantari, O. Mohd Tahir, N. Golkar, and N. A. Ismail, "SocioCultural Development of Tajan Riverfront, Sari, Iran," Adv. Environ. Biol., vol. 9, no. 27, pp. 386-392, 2015.

[9] A. Robaro and M. O. Mamuzo, "The Impact of Socio-Kultural Environment on Entrepreneurial Emergence: An Empirical Analysis of Nigeria Society,” Eur. J. Bus. Manag., vol. 4, no. 16, p. 82, 2012.

[10] D. Budimansyah, Penguatan Pendidikan Kewarganegaraan Untuk Membangun Karakter Bangsa. Bandung: Widya Aksara Press, 2010.

[11] A. Oldfield, "Citizenship and community," Citizsh. debates A Read., vol. 1968 , no. 3, pp. 75-89, 1990.

[12] R. Dagger, Civic virtues: rights, citizenship, and republican liberalism. 1997.

[13] T. O. Kirac, M. Yildiz, and N. Cobanoglu, "Role of the News in the Education of Environmental Ethics: A Critical Approach," Procedia Soc. Behav. Sci., vol. 47, pp. 938-942, 2012.

[14] A. Burke, Communications Development: A Practical Guide, no. March. London: Department for International Development, 1999.

[15] Miles, M. B., Huberman, A. M., and Saldana, J. Qualitative data analysis. Sage. 2013.

[16] M. Bourque, "Policy Options for Urban Agriculture," no. Undp, 1996, pp. 121-148.

[17] D. Osborne and T. Gaebler, Reinventing Government: How the Entrepreneurial Spirit is Transforming the Public Sector. New York: Penguin Books Ltd, 1992.

[18] P. M. Voss, "Vertical Farming: An Agricultural Revolution on The Rise," 2012.

[19] A. Sarkar and M. Majumder, "Opportunities and Challenges in Sustainability of Vertical Eco-Farming: A Review," J. Adv. Agric. Technol., vol. 2, no. 2, 2015.
[20] E. Ellingsen and D. Despommier, "The Vertical Farm - The origin of a 21st century Architectural Typology," CTBUH J., no. 3, pp. 26-34, 2008

[21] R. Islam and C. Siwar, "The Analysis of Urban Agriculture Development in Malaysia," Adv. Environ. Biol., vol. 6, no. 3, pp. 1068 1078, 2012.

[22] G. O. Wingqvist, O. Drakenberg, D. Slunge, M. Sjostedt, and A. Ekbom, The Role of Governance For Improved Environmental Outcomes Sweden: The Swedish Environmental Protection Agency, 2012.

[23] J. L. Kimpell, "Republican civic virtue, enlightened self-interest and Tocqueville,” Eur. J. Polit. Theory, vol. 14, no. 3, pp. 345-367, 2015.

[24] H. De Zeeuw, S. Guendel, and H. Waibel, "The Integration of Agriculture in Urban Policies," in Growing cities, growing food. Urban agriculture on the policy agenda, 2000, pp. 161-180.

[25] M. Masson-Minock and D. Stockmann, "Creating a legal framework for urban agriculture: Lessons from Flint, Michigan,” J. Agric. Food Syst. Community Dev., vol. 1, no. 2, pp. 91-104, 2010.

[26] K. M. S. Islam, "Rooftop Gardening as A Atrategy of Urban Agriculture For Food Security: The Case of Dhaka City, Bangladesh," Acta Hortic., vol. 643, pp. 241-247, 2004

[27] I. Madaleno, "Urban agriculture in Belem, Brazil," Cities, vol. 17, no. 1 , pp. 73-77, 2000.

[28] R. McKeown-Ice and R. Dendinger, "Socio-Political-Cultural Foundations of Environmental Education," Environ. Educ., vol. 31, no. 4, pp. 37-45, 2010.

[29] B. K. Boogaard, S. J. Oosting, and B. B. Bock, "Defining Sustainability as a Socio-Cultural Concept: Citizen Panels Visiting Dairy Farms in the Netherlands," Livest. Sci., vol. 117, no. 1, pp. 24-33, 2008. 